\title{
Developments in the quantity and quality of endodontic publications: two sides of the same coin?
}

\author{
Eyal Rosen ${ }^{*}$ and Igor Tsesis
}

\section{The goals of medical research}

Since the beginning of modern mankind, scientists have been trying to comprehend the forces of nature. This quest for knowledge has evolved during history, as the methods to assess and analyze the data became more and more structured and controlled. In 1924, Alfred E. Cohn stated: "since the renaissance, men of science have indeed been continuously eager to escape from those influences which tended to focus their interests on the contemplation alone of natural phenomena, and have sought to enlarge knowledge by coming actually into contact with the facts and forces of nature" (Cohn 1924). He also stated that "the method of deduction in natural science as the sole method of investigation was finally abandoned and the method of induction, of experiment, was added" (Cohn 1924).

The characteristics of medical research have changed many times in the course of history. To date, the goals of medical research are as follows: to support the practitioner's clinical decision-making; to evaluate new medical techniques and technologies; to improve the practitioner's and the public's medical education; and to assist policy makers in societal medical decision-making.

There is a constant trend of increasing rates of medical research and ensuing publications. The pros of these trends are the production of new information for the benefit of the medical community and the whole society. However, the cons include the accumulation of uncontained amounts of information. As the information revolution gathers pace, it becomes more and more difficult to separate the wheat from the chaff.

\section{The goals of medical journals}

Medical journals are essentially a platform to present scientific evidence. These journals are also expected to appraise the quality and adequacy of the information,

\footnotetext{
*Correspondence: dr.eyalrosen@gmail.com

Department of Endodontology, Maurice and Gabriela Goldschleger School of Dental Medicine, Tel Aviv University, Tel Aviv, Israel
}

using a process known as "peer review"-the use of peers to assess the work of fellow scientists. These peers are usually the journal's editorial board members (Jefferson et al. 2007).

The use of peer review is expected to improve the quality of the accepted manuscripts by providing a method for rational and objective editorial decisionmaking. As evident, the growing amounts of produced scientific data have raised the burden on the editorial boards of the conservative medical journals.

\section{Developments in endodontic publications}

The development in medical publications is a coin with two sides: the trends in the quantity and the trends in the quality of the publications. The exact extent of the annually produced manuscripts in endodontics as well as their quality, are unknown. However, it is possible to estimate the numbers of accepted and published manuscripts in endodontics. Additionally, in recent years, several attempts have been made to assess the quality of publications in dentistry, as well as specifically in endodontics.

The combined quantity of annual publications in the two leading endodontic journals (Journal of Endodontics (JOE) and International Endodontic Journal (IEJ)) is constantly rising and is currently about five times more compared to 25 years ago (Fig. 1). In addition, the fact that in recent years many endodontic-related studies are being published in non-endodontic journals adds more to these numbers and highlights the acceleration in endodontic publications.

Del Fabbro et al. (2015) systematically evaluated the literature in endodontic surgery over a 10 -year period and reported a positive trend over the years in performing studies of good quality in endodontic surgery, with steadily increasing numbers of high evidencelevel articles published in the field of endodontic surgery over the years.
Springer Open 


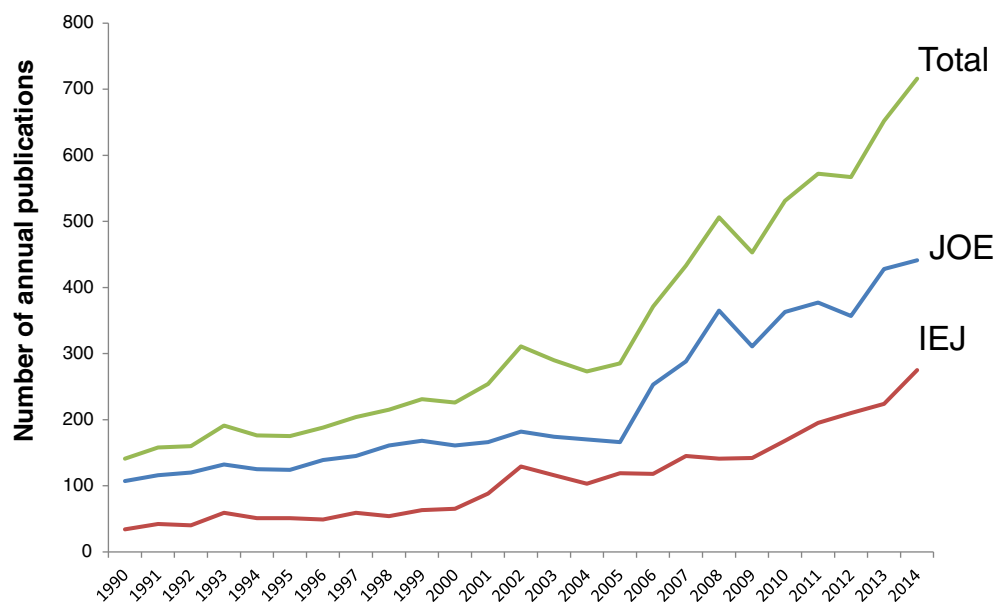

Fig. 1 Number of annual publications in the two leading endodontic journals between 1990 and 2014 (Pubmed search (e.g., JOE, 2000 - MESH received: "Journal of endodontics"[Journal] AND ("2000"[PDAT] : "2000"[PDAT]))). JOE Journal of Endodontics, IEJ International Endodontic Journal, Total JOE + IEJ

Lee et al (2014) compared the trends in publications between 2007 and 2013 in three dental specialties: endodontics, periodontics, and pediatric dentistry. They reported shifting in the global interests in these three specialties over these 7 years: there was a positive growth rate for endodontics, projecting that the annual number of publications for endodontics will increase in the future, as compared to negative growth rates for periodontology and pediatric dentistry, projecting that the annual numbers of publications in periodontology and pediatric dentistry will decrease in the future (Lee et al. 2014).

The positive developments in endodontic publication patterns in the past several decades, as evident by the number and quality of endodontic publications, indicate a constant increase in the scientific interest in endodontic research, even more than in other dental specialties.

The expected growing quantity of endodontic publications must go hand in hand with the quality of the publications: the quantity and quality of publications should be two sides of the same coin. Therefore, it seems that new endodontic journals are needed, in order to enable the containment of the growing flow of new endodontic scientific data, while keeping strict quality standards to the publications.

Evidence-Based Endodontics (EBE) is a journal that aims to present the latest and best available scientific evidence in Endodontics, with a vision to promote evidence-based clinical decision-making, education, and research.

Received: 28 November 2015 Accepted: 30 March 2016 Published online: 03 May 2016

\section{References}

Cohn AE. PURPOSES IN MEDICAL RESEARCH: an introduction to the Journal of Clinical Investigation. J Clin Invest. 1924;1 (1):1-11.

Del Fabbro M, Corbella S, Tsesis I, Taschieri S. The trend of quality of publications in endodontic surgery: a 10-year systematic survey of the literature. J Evid Based Dent Pract. 2015;15(1):2-7.

Jefferson T, Rudin M, Brodney Folse S, Davidoff F. Editorial peer review for improving the quality of reports of biomedical studies. Cochrane Database Syst Rev. 2007;2:MR000016.

Lee E, Chin B, Lin J, Lin C, Hershkowitz D, Goren AD, et al. A bibliometric analysis of the characteristics and trends in dental research: a survey of research articles published in selective dental journals between 2007 and 2013, evaluating three dental specialties. JSM Dent. 2014;2(5):1047.

\section{Submit your manuscript to a SpringerOpen ${ }^{\circ}$} journal and benefit from:

- Convenient online submission

- Rigorous peer review

- Immediate publication on acceptance

- Open access: articles freely available online

- High visibility within the field

- Retaining the copyright to your article

Submit your next manuscript at $\boldsymbol{s p r i n g e r o p e n . c o m ~}$ 